PETHŐ László, BÁRDOSNÉ K. Zsuzsanna, MASSZI Zsófia, LUKA Flóra

BFKH Népegészségügyi Föosztály, Budapest

E-mail: petho.laszlo@nfo.bfkh.gov.hu

DOI: https://doi.org/10.29179/EgTud.2021.3.36

\title{
A Campylobacter kimutatás rejtelmei
}

\section{Összefoglalás:}

Évek óta a campylobacteriosis lényegesen magasabb megbetegedésszámot produkál az EU-ban, minta a salmonellosis. (2019. évben 220000 vs. 88 000.) Hazánk a 65 eset/100 000 fő arányszámmal a közepesen fertőzött kategóriába sorolható.

Vizsgálataink során kiskereskedelmi forgalomban kapható szárnyashúsokat vizsgáltunk, mely minták 75\%-a pozitívnak bizonyult Campylobacter spp. tekintetében. Összevetésben a korábbi évek eredményeivel ez igen magas értéknek számít, amit a célzott mintavételezés mellett a kimutatási módszerek finomításának köszönhetünk. Laboratóriumunkban tesztmintákon több gyártótól származó elődúsítót és szelektív táptalajt kipróbáltunk, valamint a mikroaerofil környezet előállításához használt edényzet megfelelő feltöltésével is kísérleteztünk. A tenyésztéses vizsgálatokat minden esetben qPCR méréssel ellenőriztük. A tapasztalatok azt mutatták, hogy az erős háttér-mikrobióta a legjelentősebb hibaforrás a táptalajról történő visszanyerésben, azonban az erősebb gátló hatással bíró táptalaj az alacsony csíraszámban jelenlevő Campylobacter spp.-t is gátolhatja. A háttér-mikrobióta kizárására hatékonynak bizonyult a szakirodalomban leírt, ám a kimutatási szabványban nem említett membránszúréses módszer. Ennek során, kihasználva a baktériumtörzs átlagosnál kisebb méretét és mozgé-

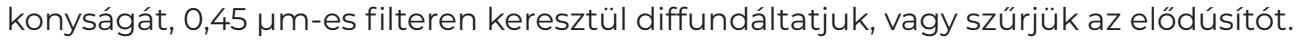

A minták 30\%-ából voltak Salmonella törzsek kimutathatóak, és jellemzően a Campylobacterrel együttesen fordultak elő.

Az igazolt campylobacteriosis eseteket telefonos megkereséssel, kérdőíves adatgyűjtéssel próbáltuk felmérni. Sajnos a tapasztalatok alapján annyira hosszú a latencia idő, mire a járványügy értesül az esetről (laboratóriumi vizsgálat és bejelentés késlekedése miatt), hogy az élelmiszerrel kapcsolatos információk elhalványulnak.

A laboratóriumi vizsgálatok eredménye alapján jelenleg leginkább a jó konyhai gyakorlatnak köszönhetjük, hogy nem magasabb a megbetegedések száma. Bár a nyers szárnyashúsok elkészítésekor általános hőkezelés megfelelő sterilizáló hatással bír, az eszközökön, felületeken történő keresztszennyezést nem mindig könnyű kivédeni. Annak érdekében, hogy csökkenjen a campylobacteriosis száma érdemes lenne nagyobb figyelmet fordítani a járványügyi kivizsgálásra, és kiterjedtebben alkalmazni a laboratóriumi vizsgálatokat is. Különös aktualitást ad a témának, a Campylobacter jejuni által kiváltott Guillain-Barré szindróma, mely már bizonyos COVID-19 vaktorvakcinák mellékhatásaként is feltünt.

Kulcsszavak: campylobacter, salmonella, qPCR, húsok 